\title{
TANGGUNG JAWAB HUKUM DOKTER TERHADAP TINDAKAN PENCABUTAN GIGI SULUNG PADA PROGRAM UKGS
}

\author{
Sulaeman \\ Alumni Magister Ilmu Hukum \\ Pascasarjana Universitas Islam Bandung \\ Dokter Gigi Madya di Dinas Kesehatan Kabupaten Tasikmalaya \\ Email : sulaemanskg@gmail.com
}

\begin{abstract}
Abstrak : Ketidaksinkronan antara pelaksanaan penerapan informed consent secara masal dengan peraturan perundang-undangan, menjadikan tindakan pencabutan gigi pada program UKGS di sekolah belum memiliki perlindungan hukum. Pada prinsipnya informed consent harus diterapkan pada tindakan pencabutan gigi sulung yang persisten atau sudah goyang. Tujuan dari tulisan ini adalah untuk memahami penerapan informed consent tindakan pencabutan gigi pada program Usaha Kesehatan Gigi Sekolah yang dapat memberikan perlindungan hukum baik bagi sasaran maupun pelaksana program, serta untuk memahami tanggung jawab hukum dokter dan tenaga kesehatan apabila terjadi insiden sehubungan dengan tindakan pencabutan gigi pada program Usaha Kesehatan Gigi Sekolah. Penelitian ini dilakukan menggunakan pendekatan yuridis normatif, yang bersifat deskriptif analisis. Teknik pengumpulan data melalui kepustakaan (Library Research), dan teknik analisis kualitatif normatif dengan cara melakukan penafsiran, korelasi, dan perbandingan terhadap bahan-bahan hukum. Hasil penelitian menyimpulkan bahwa apabila tindakan pencabutan gigi yang dilakukan secara massal di masyarakat yaitu di sekolah pada program UKGS, maka persetujuan untuk tindakan tersebut tidak diperlukan. Dan apabila insiden tetap terjadi dan penyampaian informasi tentang tindakan telah dilakukan serta tidak ada unsur melawan hukum, maka dokter atau tenaga kesehatan dan pemerintah tidak dapat dimintakan pertanggungjawaban baik secara administratif, perdata, maupun pidana
\end{abstract}

Kata Kunci : informed consent, gigi sulung, persistensi, pencabutan, UKGS

\begin{abstract}
The asynchrony between the implementation of mass informed consent application and statutory regulations has made the action of tooth extraction in the UKGS program in schools not yet legally protected. In principle, informed consent should be applied to the action of persistent or loose primary tooth extraction. The purpose of this study was to understand the application of informed consent for tooth extraction in the UKGS program, which can provide legal protection for both program targets and implementers, and to comprehend the legal responsibility of doctors and health workers in the event of an incident related to tooth extraction in the UKGS program. This study was conducted using a normative juridical approach, which is descriptive analysis through library research as its data collection technique, and normative qualitative analysis technique by means of interpretation, correlation, and comparison of legal materials. The result concluded that if the act of tooth extraction was conducted massively in the community, namely in schools in the UKGS program, then approval for the action was not required. Additionally, if the incident still occurs, information about the action has been conveyed and there is no element against the law, then doctors or health workers and the government cannot be held accountable either in administrative, civil, or criminal way.
\end{abstract}

Keywords : informed consent, primary tooth, persistence, extraction, UKGS 


\section{A. PENDAHULUAN}

Kesehatan sebagai hak asasi manusia harus diwujudkan dalam bentuk pemberian upaya kesehatan yang berkualitas. Pemberian upaya kesehatan dalam pandangan agama Islam merupakan upaya melindungi jiwa (hifzun nafs) sebagai bagian dari tujuan syariah (maqaasyidus syariah). (Kementerian Agama RI, 2013 : 55). Di dalam Undang-Undang Dasar 1945 dan Amandemennya Pasal $28 \mathrm{H}$ ayat (1) disebutkan bahwa setiap orang berhak hidup sejahtera lahir dan batin, bertempat tinggal, dan mendapat lingkungan hidup yang baik dan sehat serta berhak memperoleh layanan kesehatan. Dan pada Pasal 34 ayat (3) disebutkan bahwa negara bertanggung jawab atas penyediaan pelayanan kesehatan dan fasilitas pelayanan umum yang layak. Undang-Undang Nomor 23 Tahun 2003 tentang Perlindungan Anak Pasal 44 menyatakan bahwa Pemerintah wajib menyediakan fasilitas dan menyelenggarakan upaya kesehatan yang komprehensif bagi anak, agar setiap anak memperoleh derajat kesehatan yang optimal sejak dalam kandungan. Penyediaan fasilitas dan penyelenggaraan upaya kesehatan secara komprehensif sebagaimana dimaksud harus didukung oleh peran serta masyarakat. Upaya kesehatan yang komprehensif tersebut meliputi upaya promotif, preventif, kuratif, dan rehabilitatif, baik untuk pelayanan kesehatan dasar maupun rujukan.

Berbagai peraturan perundangundangan telah mengatur tentang penerapan informed consent dalam melakukan tindakan medik. UndangUndang Nomor 29 Tahun 2004 tentang Praktik Kedokteran Pasal 45 menyebutkan bahwa setiap tindakan kedokteran atau kedokteran gigi yang akan dilakukan oleh dokter atau dokter gigi terhadap pasien harus mendapat persetujuan. Persetujuan sebagaimana dimaksud diberikan setelah pasien mendapat penjelasan secara lengkap. Sebagai petunjuk teknis pelaksanaan Pasal 45 Undang-Undang Nomor 29 Tahun 2004 tentang Praktik Kedokteran tersebut adalah Peraturan Menteri Kesehatan Nomor 290 Tahun 2008 tentang Persetujuan Tindakan Kedokteran. Di dalam Permenkes Nomor 290 Tahun 2008 tentang Persetujuan Tindakan Kedokteran 
Pasal 2 ayat (1) disebutkan bahwa semua tindakan kedokteran yang akan dilakukan terhadap pasien harus mendapat persetujuan. Dan pada Pasal 7 menyebutkan bahwa penjelasan tentang tindakan kedokteran harus diberikan langsung kepada pasien dan/atau keluarga terdekat, baik diminta maupun tidak diminta. Namun ada hal berbeda dimana pada Pasal 15 disebutkan bahwa dalam hal tindakan kedokteran harus dilaksanakan sesuai dengan program pemerintah dimana tindakan medik tersebut untuk kepentingan masyarakat banyak, maka persetujuan tindakan kedokteran tidak diperlukan. Undang-Undang Nomor 36 Tahun 2009 tentang Kesehatan Pasal 5 ayat (3) mengatakan bahwa setiap orang mempunyai hak dalam memperoleh layanan kesehatan yang aman, bermutu, dan terjangkau. Selanjutnya pada Pasal 8 menyebutkan bahwa setiap orang berhak mendapatkan informasi dan edukasi tentang kesehatan yang seimbang dan bertanggung jawab. Sedangkan pada Pasal 56 disebutkan bahwa setiap orang berhak menerima atau menolak sebagian atau seluruh tindakan pertolongan yang akan diberikan kepadanya setelah menerima dan memahami informasi mengenai tindakan tersebut secara lengkap.

Upaya pelayanan kesehatan di Puskesmas mencakup upaya pelayanan kesehatan perorangan dan upaya pelayanan kesehatan masyarakat. Undang-Undang Nomor 36 Tahun 2009 tentang Kesehatan Pasal 92 ayat (3) menetapkan bahwa salah satu program yang termasuk dalam upaya kesehatan masyarakat di bidang kesehatan gigi dan mulut yaitu program Usaha Kesehatan Gigi Sekolah (UKGS). Berdasarkan Keputusan Direktur Jenderal Bina Upaya Kesehatan Nomor: HK.02.04/II/963/2012 tentang Pedoman Usaha Kesehatan Gigi Sekolah (UKGS) bahwa salah satu kegiatan UKGS bidang upaya kesehatan perorangannya adalah pencabutan gigi sulung yang sudah waktunya tanggal (persistensi). (Kementerian Kesehatan RI, 2012 : 16-17). Pencabutan gigi pada anak SD terutama kasus gigi goyang dan persistensi sangat penting agar pertumbuhan gigi geligi permanennya dapat tumbuh dengan susunan yang 
baik yang pada gilirannya akan mengurangi potensi terjadinya gigi berlubang. Penerapan informed consent pada program Usaha Kesehatan Gigi Sekolah khususnya tindakan pencabutan gigi sulung menghadapi banyak kendala.

Walaupun peraturan perundangundangan telah mengamanatkan bahwa setiap tindakan kedokteran harus dilakukan informed consent, namun pada pelaksanaannya secara teknis sulit dilakukan karena jumlah sasaran siswa SD yang cukup banyak, kendala jarak dan waktu untuk memberikan informed kepada orang tua siswa, kendala logistik yang cukup besar, kendala sumber daya manusia kesehatan yang sangat terbatas, dan faktor latar belakang sosial ekonomi orang tua siswa yang sangat beragam.

Sebagai gambaran misalnya di wilayah kerja salah satu Puskesmas di Kabupaten Tasikmalaya pada tahun 2014 terdapat sejumlah 35 SD/MI dengan total siswa sekitar 8400 orang. Jarak SD terdekat sekitar kurang dari satu kilometer dan terjauh sekitar 5 kilometer dari Puskesmas induk yang hanya dapat dijangkau dengan kendaraan roda dua. Topografi wilayah $70 \%$ berupa perbukitan dan sisanya dataran rendah. Jumlah tenaga kesehatan gigi yang tersedia satu dokter gigi dan dua perawat gigi. Dari jumlah tenaga kesehatan yang ada itu harus membagi fokus pelayanan kepada pelayanan rawat jalan dalam gedung puskesmas dan sekaligus pelayanan luar gedung baik di sekolahsekolah maupun posyandu. (UPT Puskesmas DTP Ciawi Kabupaten Tasikmalaya, 2015 : 10). Dengan kondisi demikian maka apabila untuk menerapkan informed consent harus dengan menghadirkan orang tua ke sekolah satu persatu, maka akan memerlukan waktu yang cukup lama, logistik yang besar, SDM yang banyak, dan biaya yang tidak sedikit. Padahal Permenkes Nomor 290 Tahun 2008 tentang Persetujuan Tindakan Kedokteran mengatakan bahwa semua tindakan kedokteran yang akan dilakukan terhadap pasien harus mendapat persetujuan. Dan penjelasan tentang tindakan kedokteran itu harus diberikan langsung kepada pasien dan/atau keluarga terdekat. Walaupun pada Pasal 15 disebutkan bahwa dalam hal tindakan kedokteran harus 
dilaksanakan sesuai dengan program pemerintah dimana tindakan medik tersebut untuk kepentingan masyarakat banyak, maka persetujuan tindakan kedokteran tidak diperlukan. Dan tindakan pencabutan gigi sulung yang sudah goyang dan persistensi adalah bagian dari program UKGS yang merupakan program pemerintah.

Adanya kesulitan teknis pada pelaksanaan penerapan informed consent secara massal dan adanya peraturan perundang-undangan yang belum sinkron menjadikan tindakan pencabutan gigi pada program UKGS belum memiliki perlindungan hukum bagi pelaksana pelayanan kesehatan maupun sasarannya.

Dengan demikian dapat
didefinisikan masalahnya adalah: Pertama, bagaimana penerapan informed consent tindakan pencabutan gigi sulung yang persistensi atau sudah goyang pada program Usaha Kesehatan Gigi Sekolah dapat memberikan perlindungan hukum baik bagi sasaran maupun pelaksana program? Kedua, Bagaimana tanggung jawab hukum dokter dan tenaga kesehatan apabila terjadi insiden sehubungan dengan tindakan

pencabutan gigi sulung yang persistensi atau sudah goyang pada program Usaha Kesehatan Gigi Sekolah?

Sesuai dengan rumusan identifikasi masalah di atas maka tujuan penelitian adalah: Kesatu, untuk memahami penerapan informed consent tindakan pencabutan gigi pada program Usaha Kesehatan Gigi Sekolah yang dapat memberikan perlindungan hukum baik bagi sasaran maupun pelaksana program. Kedua, untuk memahami tanggung jawab hukum dokter dan tenaga kesehatan apabila terjadi insiden sehubungan dengan tindakan pencabutan gigi pada program Usaha Kesehatan Gigi Sekolah.

Pendekatan yang digunakan dalam penelitian ini adalah yuridis normatif atau penelitian hukum normatif, yakni dengan mempelajari dan menelaah hukum sebagai suatu kaidah atau sistem kaidah-kaidah hukum normatif di bidang hukum. (Johny Ibrahim, 2005 : 49-52). Dalam penyusunan dan penulisan penelitian ini dipergunakan spesifikasi penelitian yang bersifat 
deskriptif analisis. Penelitian deskriptif analitis berupaya mengungkapkan aturan perundang-undangan yang berkaitan dengan teori-teori hukum yang menjadi objek penelitian. Demikian juga hukum dalam pelaksanaannya di masyarakat yang berkenaan dengan objek penelitian. Maksudnya adalah penelitian ini berusaha menginventarisasi hukum positif (perjanjian teurapeutik) dan mengklasifikasikan hukum positif itu menjadi berbagai kategori hukum. (Ibid : 105-106). Teknik pengumpulan data dalam penelitian ini dilakukan melalui cara penelitian kepustakaan (Library Research) melalui penelusuran bahan pustaka. (Soerjono Soekanto, 2001 : 14). Bahan pustaka tersebut meliputi bahan hukum primer (primer sources of authorities) berupa ketentuan perundang-undangan, bahan hukum sekunder (secondary sources of authorities) berupa buku-buku teks, litaratur dan tulisan-tulisan para ahli pada umumnya. Selain itu dilakukan penelusuran landasan teoritis berupa pendapat-pendapat para ahli atau informasi dari pihak berwenang. (Op.Cit : 47-56). Bahan-bahan yang dikumpulkan dianalisis dengan menggunakan teknik analisis kualitatif normatif yaitu dengan cara melakukan penafsiran, korelasi, dan perbandingan terhadap-bahan-bahan hukum yang membahas penerapan informed consent tindakan pencabutan gigi pada program UKGS. Analisis data dilakukan dengan menarik kesimpulan secara induktif (Lexy J. Moleong, 2004 : 296-298). Berdasarkan hasil penelaahan peraturan-peraturan dan bahan-bahan hukum terkait. (Op.Cit : 107).

\section{B. PEMBAHASAN}

\section{Penerapan Informed Consent} Tindakan Pencabutan Gigi pada Program UKGS dan Perlindungan Hukum

Pada dasarnya pada setiap tindakan kedokteran harus diterapkan informed consent. Termasuk di dalamnya tindakan pencabutan gigi sulung yang persistensi atau sudah goyang juga dalam pelaksanaannya membutuhkan informed consent. Dalam Undang-Undang Nomor 29 Tahun 2004 tentang Praktik Kedokteran, Di dalam Pasal 39 dinyatakan bahwa praktik kedokteran diselenggarakan berdasarkan 
kesepakatan antara dokter atau dokter gigi dengan pasien dalam upaya untuk memelihara kesehatan, pencegahan penyakit, peningkatan kesehatan, pengobatan penyakit, dan pemulihan kesehatan. Kata "kesepakatan" menunjukkan bahwa setiap tindakan kedokteran atau kedokteran gigi yang akan dilakukan oleh dokter atau dokter gigi terhadap pasien harus mendapat persetujuan (informed consent). Pada Pasal 45 dinyatakan bahwa setiap tindakan kedokteran atau kedokteran gigi terhadap pasien harus mendapat persetujuan setelah pasien mendapatkan penjelasan secara lengkap. Kemudian sebagai peraturan pelaksanaan undang-undang tersebut di atas yaitu Peraturan Menteri Kesehatan Nomor 290 Tahun 2008 tentang Persetujuan Tindakan Kedokteran Pasal 2 menyatakan bahwa semua tindakan kedokteran yang akan dilakukan terhadap pasien harus mendapat persetujuan secara tertulis maupun lisan setelah mendapat penjelasan yang diperlukan tentang perlunya tindakan kedokteran dilakukan.

Untuk memberikan penjelasan lebih lanjut mengenai Persetujuan
Tindakan Kedokteran tersebut maka Konsil Kedokteran Indonesia (KKI) sebagai lembaga yang dibentuk berdasarkan Undang-Undang Nomor 29 Tahun 2004 tentang Praktik Kedokteran telah menerbitkan buku Manual Persetujuan Tindakan Kedokteran. Dalam buku tersebut dinyatakan bahwa suatu tindakan kedokteran atau kedokteran gigi dilakukan terhadap pasien untuk tujuan preventif, diagnostik, terapeutik dan rehabilitatif. (Oktarina, Kebijakan Informed Consent dalam Pelayanan Gigi di Indonesia, Jurnal Manajemen Pelayanan Kesehatan, Vol. 13, No. 1 Maret 2010 :6-7). Demikian juga di dalam Undang-undang Nomor 36 Tahun 2009 tentang Kesehatan Pasal 56 yang bunyinya setiap orang berhak menerima atau menolak sebagian atau seluruh tindakan pertolongan yang akan diberikan kepadanya setelah menerima dan memahami informasi mengenai tindakan tersebut secara lengkap. Pemenuhan hak-hak pasien juga selaras dengan Undang-Undang Nomor 8 Tahun 1999 tentang Perlindungan Konsumen Pasal 4 yang antara lain menyatakan bahwa hak konsumen adalah hak atas 
kenyamanan, keamanan, dan keselamatan dalam mengkonsumsi barang dan/atau jasa dan hak atas informasi yang benar, jelas, dan jujur mengenai kondisi dan jaminan barang dan/atau jasa.

Namun demikian apabila tindakan pencabutan gigi sulung yang persistensi atau sudah goyang tersebut pada program UGKS dilaksanakan sebagai bagian dari program pemerintah, maka pada pelaksanaannya menurut peraturan perundang-undangan tidak memerlukan persetujuan tindakan. Dalam Undang-Undang Nomor 36 Tahun 2014 tentang Tenaga Kesehatan disebutkan bahwa pelayanan kesehatan masyarakat yang ditujukan untuk kepentingan masyarakat yang merupakan program Pemerintah tidak memerlukan persetujuan tindakan. Namun demikian, tindakan tersebut tetap harus diinformasikan kepada masyarakat Penerima Pelayanan Kesehatan tersebut. Hal ini senada dengan bunyi Peraturan Menteri Kesehatan Nomor 290/MENKES/PER/III/2008 tentang Persetujuan Tindakan Kedokteran Pasal 15 yaitu bahwa dalam hal tindakan kedokteran harus dilaksanakan sesuai dengan program pemerintah dimana tindakan medik tersebut untuk kepentingan masyarakat banyak, maka persetujuan tindakan kedokteran tidak diperlukan. Menurut hukum, pemberian pertolongan medis harus menjamin otorisasi atau wewenang yang seharusnya sebelum melakukan prosedur diagnosa atau terapi pada seorang pasien.

$\begin{array}{lr}\text { Namun dalam } & \text { beberapa } \\ \text { keadaan terbatas, } & \text { hukum } \\ \text { mengenyampingkan } & \text { keputusan }\end{array}$
persetujuan pasien dan memberikan hak untuk dilakukannya pengobatan di luar kehendak pasien. Misalnya dalam keadaan darurat, dan tanggung jawab sipil terhadap penderita mental atau sakit jiwa, serta penyalahgunaan sesuatu. Program UKGS sifat hukumnya adalah hukum publik, yakni menyangkut hubungan hukum (baca kepentingan) antara pemerintah/negara dengan warga negara/penduduknya. Program UKGS dijalankan sebagai kewajiban (akrab disebut : tugas) pemerintah dalam suatu negara demi kepentingan rakyatnya (dikenal sebagai : hak rakyat). (Amrah Muslimin, 1970). 
Dalam perkembangannya saat ini setiap orang wajib dan bertanggung jawab tentang kesehatan (termasuk kesehatan gigi dan mulut), yang ditandai adanya peran swasta (termasuk profesi dokter praktek swasta) dalam program kesehatan. (Dasar Falsafah Negara: Pancasila, Dasar Konstitusi: UUD 1945, Dasar Operasional: GBHN yang Memuat Wawasan Nusantara Dan Ketahanan Nasional). Karenanya sifat hukumnya adalah menyelenggarakan upaya kesehatan dalam rangka kesejahteraan umum, melalui (sistem) pemerintahan sebagai tugas administrasi negara, sehingga kajian program UKGS termasuk dalam hukum administrasi negara. Kebijakan tentang tindakan pencabutan gigi sulung yang persistensi atau sudah goyang diatur dalam Keputusan Direktur Jenderal Bina Upaya Kesehatan Nomor: HK.02.04/II/963/2012 tentang Pedoman Usaha Kesehatan Gigi Sekolah (UKGS) mengenai strategi dan langkah untuk mencapai target kesehatan gigi dan mulut dengan pentahapan paket UKGS di sekolah. Dalam pentahapan UKGS tersebut disebutkan bahwa untuk tindakan pencabutan gigi sulung yang sudah waktunya tanggal dilakukan dengan informed consent tertulis dari orang tua dan tindakan dilakukan oleh tenaga kesehatan gigi.

Tindakan pencabutan gigi sulung yang persistensi atau sudah goyang pada program UGKS juga berdampak pada masyarakat banyak, sehingga pada pelaksanaannya menurut peraturan perundangundangan tidak memerlukan persetujuan tindakan. Penyakit gigi dan mulut merupakan penyakit masyarakat yang diderita oleh $90 \%$ penduduk Indonesia dan bersifat progresif, karena apabila tidak dilakukan perawatan atau diobati akan semakin parah. (Departemen Kesehatan RI, 2002). Hasil Riset Kesehatan Dasar tahun 2018 menunjukkan bahwa mayoritas masyarakat Indonesia yaitu sebesar 57,6\% mengalami masalah kesehatan gigi dan mulut. Dan hanya 10,2\% yang mendapat pelayanan dari tenaga medis gigi. (Hasil Riset Kesehatan Dasar Kemenkes RI tahun 2018).

Pertanyaannya apakah tindakan pencabutan gigi sulung yang persistensi atau sudah goyang yang 
dilaksanakan di lapangan pada program UKGS termasuk dalam kriteria tindakan yang dimaksud oleh Undang-Undang Nomor 36 Tahun 2014 tentang Tenaga Kesehatan dan Peraturan Menteri Kesehatan Nomor 290/MENKES/PER/III/2008 tentang Persetujuan Tindakan Kedokteran atau tidak. Apabila tindakan pencabutan gigi sulung dianggap bukan tindakan yang berpengaruh kepada masyarakat banyak maka untuk tindakan tersebut tetap harus mendapatkan persetujuan. Namun kalau mengikuti UndangUndang Nomor 36 Tahun 2014 tentang Tenaga Kesehatan dan atau merujuk kepada Peraturan Menteri Kesehatan Nomor 290/MENKES/PER/III/2008 dengan menganggap tindakan tersebut berdampak "untuk kepentingan masyarakat banyak" maka tindakan pencabutan gigi sulung termasuk di dalamnya dan oleh karenanya tindakan tersebut tidak memerlukan persetujuan tapi cukup diinformasikan saja. Adapun pedoman UKGS yang menyebutkan penerapan informed consent tertulis oleh orang tua siswa dapat dipandang sebagai upaya preventif dan kehati-hatian untuk mencegah terjadinya tuntutan dari orang tua pasien apabila terjadi insiden.

Tindakan pencabutan gigi sulung yang persistensi atau sudah goyang pada program UGKS juga sudah pada tahap kedaruratan, sehingga pada pelaksanaannya menurut peraturan perundangundangan tidak memerlukan persetujuan tindakan. Dalam hal keadaan darurat misalnya dalam program imunisasi untuk mencegah merebaknya wabah penyakit polio, campak, dan lain-lain. Tindakan pencabutan gigi sulung yang persistensi atau sudah goyang memang tidak dapat dikategorikan keadaan darurat. Tetapi walaupun tidak mengancam jiwa dan menyebar ke masyarakat banyak namun dampaknya terhadap individu penderita sangat besar dan sebarannya (prevalensinya) di masyarakat sangat luas. Hal yang hampir serupa dengan imunisasi karena dilakukan secara massal di masyarakat adalah tindakan pencabutan gigi sulung yang persistensi atau sudah goyang. Tindakan tersebut merupakan tindakan preventif yang memiliki pengaruh 
besar dan luas bagi kesehatan gigi dan mulut khususnya dan kesehatan umumnya. Tindakan tersebut dilakukan pada periode emas (golden age) sasaran yaitu pada anak-anak sekolah dengan rentang usia 6-12 tahun (usia siswa Sekolah Dasar). Periode tersebut adalah periode masa peralihan dari periode gigi sulung ke periode gigi permanen. Apabila proses pergantian gigi-geligi berlangsung baik, maka susunan gigi-geligi tetap akan baik. Namun apabila sebaliknya, dimana gigi-geligi sulung terlambat tanggal (persistensi), maka akibatnya akan menghambat proses erupsi gigigeligi tetapnya sehingga besar kemungkinan susunannya menjadi tidak baik atau berjejal. Susunan gigigeligi yang tidak baik akan menyulitkan proses pemeliharaan kebersihannya dan akibatnya akan meningkatkan potensi terjadinya karies atau gigi berlubang.

Hasil Riset Kesehatan Dasar
atau Riskesdas Tahun 2018
menyebutkan bahwa 93 persen anak
usia dini, yakni dalam rentang usia 5-6
tahun, mengalami gigi berlubang. Ini
berarti hanya tujuh persen anak di
Indonesia yang bebas dari masalah

karies gigi. Disampaikan Anton Raharjo dari Fakultas Kedokteran Gigi Universitas Indonesia, hasil Riskesdas 2018 ini juga menunjukkan bahwa rata-rata anak-anak usia 5-6 tahun mengalami lubang pada delapan giginya. Hal ini menurutnya bisa memengaruhi status gizi anak karena gigi berlubang membuat anak menolak untuk makan. (Vania Rossa dan Firsta Noodia, Duh, 2019).

Program UKGS sifat hukumnya adalah hukum publik, yakni menyangkut hubungan hukum (baca kepentingan) antara pemerintah/negara dengan warga negara/penduduknya. Program UKGS dijalankan sebagai kewajiban (akrab disebut : tugas) pemerintah dalam suatu negara demi kepentingan rakyatnya (dikenal sebagai : hak rakyat). (Amrah Muslimin, Op.Cit, 1970). Dalam perkembangannya saat ini setiap orang wajib dan bertanggung jawab tentang kesehatan (termasuk UKGS), yang ditandai adanya peran swasta (termasuk profesi dokter praktek swasta) dalam program kesehatan. (Dasar Falsafah Negara: Pancasila, Dasar Konstitusi: UUD 1945, Dasar Operasional: GBHN yang Memuat 
Wawasan Nusantara dan Ketahanan Nasional). Karenanya sifat hukumnya adalah menyelenggarakan upaya kesehatan dalam rangka kesejahteraan umum, melalui (sistem) pemerintahan sebagai tugas administrasi negara, sehingga kajian program UKGS termasuk dalam hukum administrasi negara.

\section{Tanggung Jawab Hukum Dokter} dan Tenaga Kesehatan dalam Hal Terjadi Insiden dalam Tindakan Pencabutan Gigi pada Program UKGS

Dalam tindakan pencabutan gigi sulung yang persistensi atau sudah goyang pada program UKGS terdapat kemungkinan terjadinya insiden. Walaupun kemungkinannya sangat kecil, peluang untuk terjadi insiden tetap ada. Insiden yang kemungkinan dapat terjadi antara lain: insiden salah cabut, terjadinya perdarahan yang sulit berhenti akibat penyakit haemofilia atau sebab lain, pasien dengan penyakit sistemik yang kambuh saat pencabutan, tindakan cabut tanpa persetujuan, dan lain-lain.

Secara hukum siapa pun juga yang menimbulkan atau mendatangkan kerugian pada orang lain diharuskan untuk mempertanggungjawabkan segala kerugian tersebut. Demikian juga dengan dokter atau tenaga kesehatan yang telah memberikan pelayanan kesehatan (tindakan medis) kepada pasien, dalam hal telah mendatangkan kerugian dengan pelayanannya tersebut, wajib memberikan pertanggungjawaban. Tanggung jawab dokter yang melakukan malpraktik dapat ditinjau dari 3 (tiga) segi, yaitu segi keperdataan, kepidanaan, dan administrasi. (Zaeni Asyhadie, 2017 : 125). Dokter gigi Puskesmas atau tenaga kesehatan selaku pejabat lapangan maupun pejabat Kemenkes lainnya (atasannya, selaku responden superior) bisa digugat bila melakukan penyimpangan: administratif (digugat PTUN), pidana karena pelanggaran jabatan dalam KUHP, dan perdata bila menimbulkan kerugian warga masyarakat (dalam hal ini korban insiden akibat pencabutan gigi sulung yang persistensi atau sudah goyang). Dalam hal penyimpangan administratif, sebelum diajukan ke PTUN, terlebih dulu ditempuh prosedur administratif yang telah ditetapkan oleh pejabat Kemenkes 
yang berwenang. (Agus Purwadianto, Aspek Hukum KIPI (Kejadian Ikutan Pasca Imunisasi), Sari Pediatri, Vol. 2, No. 1 Juni 2000 : 19).

Tanggung jawab malpraktik dalam bidang hukum administrasi, antara lain apabila berpraktik tanpa ijin, melanggar kewajiban menyimpan rahasia kesehatan pasien (Op.Cit., Hlm. 128) dan bila dokter atau tenaga kesehatan tidak menerapkan informed consent. Namun apakah dokter atau tenaga kesehatan yang tidak menerapkan informed consent dalam tindakan pencabutan gigi sulung yang persistensi atau goyang pada program UKGS dapat dianggap melakukan malpraktik administrasi? Oleh karena dalam tindakan pencabutan gigi sulung yang persistensi atau goyang pada program UKGS hanya dibebankan kewajiban menyampaikan informasi (informed) saja tetapi tidak diwajibkan mendapatkan persetujuan (consent), maka apabila kewajiban menyampaikan informasi tersebut telah dilakukan, dokter dan tenaga kesehatan tidak dapat diminta pertanggungjawaban secara administratif. Dari segi keperdataan tanggung jawab dokter jika melakukan kesalahan dalam menjalankan profesinya (malpraktik) terbatas pada tanggung jawab yang timbul sebagai akibat adanya kontrak/perjanjian yang terjadi antara kedua belah pihak (dokter dan pasien). Dalam hal yang demikian, maka dokter yang tidak menjalankan profesinya, secara keperdataan dapat dituntut bahwa yang bersangkutan telah melakukan wanprestasi (Pasal 1239 KUHPerdata), melakukan perbuatan melanggar hukum (Pasal 1365 KUHPerdata), dan atau melakukan kelalaian yang mengakibatkan kerugian (Pasal 1366 KUHPerdata).

Dalam hal terjadi insiden sewaktu tindakan cabut gigi pada program UKGS di sekolah, maka perlu dipastikan terlebih dahulu apakah di dalam insiden tersebut terpenuhi unsur wanprestasi, unsur melawan hukum, atau unsur kelalaian yang mengakibatkan kerugian. Bila terpenuhi dan terbukti unsur-unsurnya maka dokter dan/atau tenaga kesehatan dapat dimintakan pertanggungjawabannya secara perdata.

Tanggung jawab kepidanaan dalam hubungan dokter dan pasien 
dapat muncul dalam tindakan medis yang dilakukan oleh dokter terhadap pasiennya. Tanggung jawab pidana yang perlu dibuktikan dengan adanya kesalahan profesional, yaitu biasanya dihubungkan dengan masalah kelalaian, dan persetujuan dari pasien yang bersangkutan. Apabila kelalaian itu ada dan tidak ada persetujuan dari pasien, maka dokter dapat diduga telah melakukan tindak pidana. (Ibid : 126128). Dokter sebagaimana individu yang lain dapat berbuat salah atau lalai dalam menjalankan tugas profesinya. Perbuatan salah dokter tersebut bisa masuk lapangan hukum pidana apabila memenuhi tiga syarat, yaitu: 1) Syarat dalam sikap batin; 2) Syarat dalam perlakuan medis, dan; 3) Syarat mengenai hal akibat.

Perbuatan lalai dokter yang merugikan pasien dapat masuk dalam lapangan hukum perdata dan/atau juga masuk lapangan hukum pidana dengan ketentuan kelalaian yang dilakukan oleh dokter tersebut dapat dibuktikan secara hukum oleh pasien. Sesungguhnya tidak selalu sulit untuk membuktikan kelalaian dokter apabila memenuhi doktrin res ipsa loquitur, yaitu suatu kelalaian yang sudah sedemikian jelasnya sehingga orang awam pun tahu bahwa telah terjadi kelalaian (the thing speak for ot self) atau "benda tersebut yang berbicara." (Nandang Sambas, 2010 : 10-11).

Setiap manusia tidak ada yang sempurna. Oleh karenanya selalu mempunyai ruang untuk melakukan kesalahan, baik itu sengaja maupun kelalaian. Dasar inilah yang kemudian dijadikan dasar di dalam hukum pidana bahwa meskipun seseorang melakukan perbuatan yang melawan hukum, namun pelaku tersebut belum dipastikan akan dikenakan pidana karena berbagai alasan yang dipengaruhi oleh situasi dan kondisi yang ada di lingkungan pelaku. Keadaan inilah yang di dalam hukum pidana dikenal dengan alasan pembenar dan alasan pemaaf yang dijadikan alasan penghapus pidana. Alasan penghapus pidana dalam teori hukum pidana dapat dibedakan menjadi tiga macam, yaitu sebagai berikut:

1. Alasan pembenar, yaitu alasan yang menghapuskan sifat melawan hukumnya perbuatan sehingga apa yang dilakukan oleh terdakwa lalu 
menjadi perbuatan yang patut dan benar.

2. Alasan pemaaf, yaitu alasan yang menghapuskan kesalahan terdakwa. Perbuatan yang dilakukan terdakwa tetap bersifat melawan hukum, jadi tetap merupakan perbuatan pidana. Akan tetapi dia tidak dipidana, karena tidak ada kesalahan.

3. Alasan penghapus penuntutan, di sini persoalannya bukan ada alasan pembenar maupun pemaaf, jadi tidak ada pikiran mengenai sifatnya perbuatan maupun sifatnya orang yang melakukan perbuatan. Akan tetapi, penegak hukum menganggap bahwa atas dasar atau kemanfaatan kepada masyarakat, sebaiknya tidak diadakan penuntutan. Maka yang menjadi pertimbangan di sini ialah kepentingan umum. Kalau perkaranya tidak dituntut, tentunya yang melakukan perbuatan tidak dapat dijatuhi pidana. (Muntaha, 2017 : 340-341).

Hukum pidana memberi ruang bagi untuk tidak dikenakan pidana, bilamana suatu perbuatan yang dilakukan terdapat alasan pembenar dan alasan pemaaf. Pada dasarnya terdapat tiga dasar yang meniadakan pidana (strafuitsluitingsgrond) bagi petugas kesehatan termasuk dokter yang diatur di dalam KUHP yaitu karena: (Ibid : 343).

1. Perbuatan yang mereka lakukan itu merupakan perbuatan untuk melaksanakan peraturan perundang-undangan seperti yang dimaksud dalam Pasal 50 KUHP;

2. Perbuatan yang mereka lakukan itu merupakan perbuatan untuk melaksanakan perintah jabatan yang telah diberikan oleh kekuasaan yang berwenang seperti yang dimaksud dalam Pasal 51 KUHP;

3. Perbuatan yang mereka lakukan itu telah mereka lakukan dalam noodtoestand 
atau dalam keadaan terpaksa seperti yang dimaksud dalam Pasal 48 KUHP.

Dalam berbagai kegiatan pelayanan kesehatan, dokter tidak hanya bertindak atas kepentingan pribadinya, melainkan juga melayani kepentingan umum atas perintah undang-undang. Undang-Undang Nomor 36 Tahun 2009 tentang Kesehatan pada Pasal 9 ayat (1) dan ayat (2) mewajibkan bagi setiap orang untuk meningkatkan derajat kesehatan kepada seluruh masyarakat, tanpa kecuali, termasuk dalam hal in dokter. Begitu juga dalam Pasal 12 UndangUndang Nomor 36 Tahun 2009 telah memberikan perintah bagi setiap orang, tidak terkecuali dokter, untuk menjaga dan meningkatkan derajat kesehatan bagi orang lain yang menjadi tanggung jawabnya. Perintah undang-undang tidak terbatas pada pelayanan kesehatan kepada masyarakat saja, namun terdapat pula perintah undang-undang untuk melakukan perbuatan melawan hukum.

Bagi dokter, apabila perintah itu dilaksanakan, maka dirinya tidak dapat dijatuhi sanksi pidana. Hal ini karena adanya perlindungan yang diatur di dalam perundan-undangan. Dokter dalam melaksanakan tugas sebagai pelayan di bidang medis pada suatu institusi, tidak hanya memposisikan diri sebagai pelayan secara individual semata, tetapi lebih dari itu mewakili negara untuk memberi pelayanan masyarakat di bidang medis. Dalam kedudukan sebagai organ pemerintahan, maka dokter dapat menerima perintah atas dasar perintah undang-undang untuk melakukan suatu tindakan medis atas nama pemerintah, dalam hal mana tindakan tersebut bisa berakibat adanya korban.

Secara proporsional, perintah untuk melakukan tindakan tersebut, dalam arti tindakan medis yang diperlukan, tidak lain untuk melindungi kepentingan yang lebih besar, yaitu kepentingan negara dan masyarakat secara menyeluruh. Keadaan yang demikian, apabila terjadi suatu perbuatan yang berakibat adanya korban, maka dokter tersebut tidak dapat dipersalahkan karena tindakan yang dilakukannya sematamata melaksanakan perintah undang- 
undang. Oleh karenanya, tindakan tersebut merupakan alasan pembenar dari dokter. Adanya alasan pembenar itu sekaligus menjadi dasarcuntuk menghapus kesalahan dari dokter yang bersangkutan. Kaitan perintah undangundang dengan medikal malapraktik adalah dokter dalam melakukan suatu tindakan medis sadar dan insaf bahwa tindakan yang ia lakukan bertentangan, tidak hanya etika profesi, tetapi juga melanggar aturan hukum.

Kondisi demikian melahirkan kepentingan dan kewajiban, maka secara proporsional dokter harus mengambil keputusan dengan mempertimbangkan kepentingan yang lebih besar dan melaksanakan kewajiban yang diperintahkan undangundang. Perbuatan yang dilakukan oleh dokter, meskipun tergolong medikal malapraktik, tetapi dokter melakukan perbuatan tersebut atas dasar perintah undang-undang, maka dokter yang melakukan tindakan medis itu tidak dapat dipidana.

Dalam menjalankan tugas pada jabatan pada institusi publik, banyak hal yang harus dilakukan oleh seorang dokter berkaitan dengan melaksanakan perintah jabatannya, dan tidak jarang dalam melaksanakan perintah tersebut berbagai risiko biasanya timbul. Risiko tersebut dapat berhubungan dengan etik profesi kedokteran, maupun hukum. Melaksanakan perintah jabatan yang berhubungan dengan hukum, dalam hal ini hukum pidana, bagi seseorang yang memegang jabatan, termasuk dokter, dilindungi oleh hukum, tentunya sepanjang perintah jabatan tersebut tidak disalahgunakan. Artinya, perintah jabatan itu dilakukan dengan itikad baik, tidak mempunyai niat lain selain dari melaksanakan perintah jabatan yang dipangkunya.

\section{PENUTUP}

\section{Kesimpulan}

1. Pada prinsipnya informed consent harus diterapkan pada tindakan pencabutan gigi sulung yang persisten atau sudah goyang. Namun apabila tindakan pencabutan tersebut dilakukan secara massal di masyarakat yaitu di sekolah pada program UKGS, maka persetujuan untuk tindakan tersebut tidak diperlukan 
karena merupakan program pemerintah, berdampak pada masyarakat banyak yaitu akibat yang ditimbulkannya mempunyai

sebaran/prevalensinya di masyarakat sangat luas, dan bersifat darurat yang walaupun tidak mengancam jiwa dan menyebar ke masyarakat banyak namun dampak yang ditimbulkannya terhadap individu penderita sangat besar. Pada tataran praktik penerapan informed consent tetap diupayakan dilaksanakan sebaik-baiknya dengan mengutamakan proses penyampaian informasi yang berkualitas tentang tindakan tersebut secara massal kepada masyarakat.

2. Terjadinya insiden dalam pelayanan kesehatan merupakan kejadian yang tidak diharapkan. Walaupun rasionya sangat kecil, insiden dapat mungkin terjadi pada tindakan pencabutan gigi sulung persisten pada program UKGS. Apabila insiden tetap terjadi dan penyampaian informasi tentang tindakan telah dilakukan serta tidak ada unsur melawan hukum, maka dokter atau tenaga kesehatan dan pemerintah tidak dapat dimintakan

pertanggungjawaban baik secara administratif, perdata, maupun pidana. Hal itu disebabkan tindakan dokter tersebut mempunyai alasan pembenar yaitu merupakan program pemerintah, penyakitnya mengancam masyarakat banyak, bersifat darurat, dan kedudukan dokter atau tenaga kesehatan sedang dalam posisi melaksanakan ketentuan undang-undang dan melaksanakan perintah jabatan.

\section{Saran}

1. Perlu dilakukan revisi dan penyempurnaan terhadap peraturan dan pedoman tentang informed consent terutama Peraturan Menteri Kesehatan Nomor 290 Tahun 2008 tentang 
Persetujuan Tindakan

memasukkan perihal mengenai tindakan preventif seperti tindakan pencabutan gigi sulung yang persistensi dan sudah goyang yang sudah waktunya tanggal pada program UKGS yang sesuai secara sosiologis dengan situasi dan kondisi di lapangan.

2. Pemerintah perlu membuat peraturan yang mengatur bahwa guru di sekolah berwenang mewakili orang tua siswa memberikan informed consent untuk tindakan medis tertentu dengan risiko rendah, dengan daya ungkit dan manfaat yang besar terhadap derajat kesehatan pada umumnya, dan merupakan program pemerintah. Di lain sisi juga pemerintah juga perlu mengatur dan memberikan kenyamanan dalam bekerja untuk dokter dan tenaga kesehatan dengan membuat pedoman tindakan di lapangan dan jaminan perlindungan hukum dengan memberikan pendampingan hukum dan keterlibatan pemerintah untuk ikut bertanggung jawab apabila ada tuntutan hukum dari masyarakat.

\section{DAFTAR PUSTAKA}

\section{A. Buku}

Badan Pengembangan dan Pembinaan Bahasa, Kamus Besar Bahasa Indonesia, Kementerian Pendidikan dan Kebudayaan Republik Indonesia, Jakarta, 2016.

Departemen Agama RI, AlQur'an dan Terjemahnya, Toha Putra, Semarang, 1989.

Ibnu Hajar Al-Asqalani, Bulughul Maram, Darul Ahya, Indonesia.

Johny Ibrahim, Teori \& Metodologi Penelitian Hukum Normatif, Cetakan Ketiga, Bayu Media Publishing, Surabaya, 2005.

Kementerian Agama RI, Maqasidusy-Syari'ah;

Memahami Tujuan Utama

Syariah, Lajnah Pentashihan Mushaf Al- 
Qur'an Badan Litbang dan

Diklat, Jakarta, 2013.

Kementerian Kesehatan RI

Direktorat Jenderal Bina

Upaya Kesehatan,

Pedoman Usaha Kesehatan

Gigi Sekolah, Kementerian

Kesehatan RI Jakarta, 2012.

Lexy J. Moleong, Metodologi

Penelitian Kualitatif,

Cetakan dua puluh (Edisi

Revisi), PT. Remaja

Rosdakarya, Bandung, 2004.

Muntaha, Hukum Pidana

Malapraktik,

Pertanggungjawaban dan

Penghapus Pidana, Sinar

Grafika, Jakarta, 2017.

Nandang Sambas, Pembaruan

Sistem Pemidanaan Anak

di Indonesia, Graha Ilmu,

Yogyakarta, 2010.

Soerjono Soekanto, Penelitian

Hukum Normatif Suatu

Tinjauan Singkat, 5th ed,

Raja Grafindo Persada,

Jakarta, 2001.

UPT Puskesmas DTP Ciawi

Kabupaten Tasikmalaya,
Laporan Tahunan Balai

Pengobatan Gigi Tahun

2014, Balai Pengobatan

Gigi UPT Puskesmas DTP

Ciawi Kabupaten

Tasikmalaya, Tasikmalaya, 2015.

Zaeni Asyhadie, Aspek-aspek Hukum Kesehatan, PT Rajagrafindo Persada, Jakarta, 2017.

\section{B. Jurnal}

Agus Purwadianto, Aspek Hukum KIPI (Kejadian Ikutan Pasca Imunisasi), Sari Pediatri, Vol. 2, No. 1 Juni 2000.

Oktarina, Kebijakan Informed Consent dalam Pelayanan Gigi di Indonesia, Jurnal Manajemen Pelayanan Kesehatan, Vol. 13, No. 1 Maret 2010.

Vania Rossa dan Firsta Noodia, Duh, 93 Persen Anak Indonesia Alami Gigi Berlubang https://fkg.ui.ac.id/, diunduh pada tanggal 26 Februari 2019.

\section{Peraturan Perundang- Undangan}




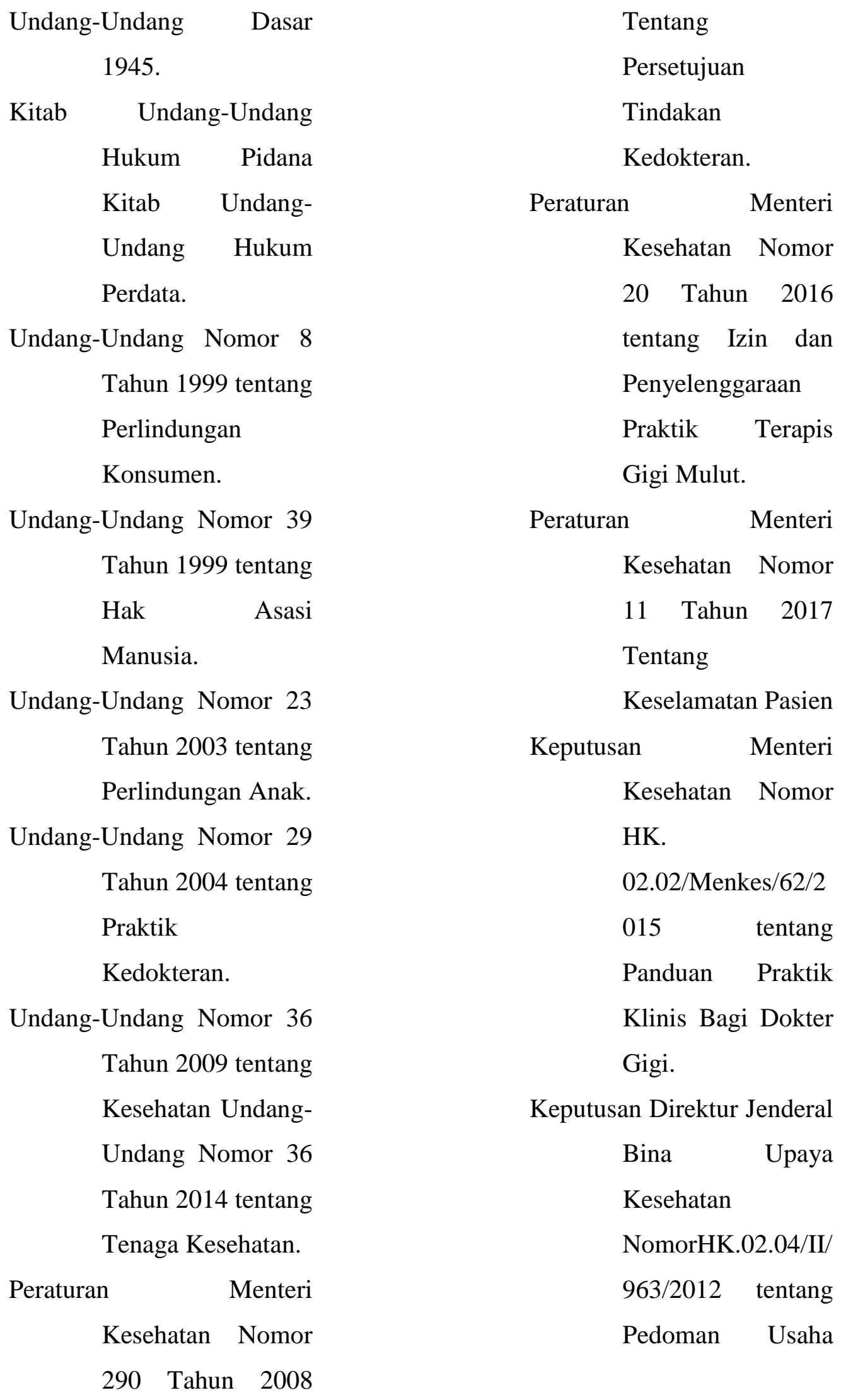


Kesehatan Gigi

Sekolah (UKGS).

D. Internet

Amrah Muslimin, Sistem,

Isi, dan Beberapa

Persoalan

Mengenai Hukum

Administrasi/Tata

Usaha Negara,

Pidato

Pengukuhan

Gurubesar

Fakultas Hukum

Universitas

Negeri Sriwijaya,

Palembang, 10

Februari 1970 